M|RIS

\title{
BULLETIN
}

January 1995

A Publication of the Materials Research Society

volume XX, Number 1 ISSN: 0883-7694 CODEN: MRSBEA

FUNCTIONALLY GRADIENT MATERIALS

14 Functionally Gradient Materials

B.H. Rabin and I. Shiota, Guest Editors

19 Overview of FGM Research in Japan

M. Koizumi and M. Niino

22 FGM Research Activities in Europe

W.A. Kaysser and B. Ilschner

27 Thermal Spray Processing of FGMs

S. Sampath, H. Herman,

N. Shimoda, and T. Saito

32 Powder Processing of Functionally Gradient Materials

R. Watanabe

35 Hierarchical Functionally Gradient Structures of Bamboo, Barley, and Corn S. Amada

37 Fundamentals of Residual Stresses in Joints Between Dissimilar Materials

B.H. Rabin, R.L. Williamson, and $S$. Suresh

40 Mathematical Modeling and Design

T. Hirano and K. Wakashima

43 Fracture Mechanics of Functionally Graded Materials F. Erdogan

\section{CVD Processing}

T. Hirai
48 Functional Gradient Structure and Properties of a Bivalve Hinge Ligament K. Ono

50 FGMs in High-Heat-Flux Environments: Cost/ Performance Issues J.J. Lannutti

52 FGM Fabrication by Combustion Synthesis G.C. Stangle and Y. Miyamoto

54 MIT-ONR Workshop Covers Functionally Graded Structural Materials S. Suresh, A. Mortenson, and $\mathrm{H}$. McManus

\section{MRS NEWS}

56 Phillips Leads MRS in 1995

\section{JMR ABSTRACTS}

64 Abstracts for March 1995 Journal of Materials Research

\section{DEPARTMENTS}

3 Letter from the President

4 Material Matters

7 Research/Researchers

11 From Washington

13 Resources

54 Conference Report

55 Upcoming Conference

60 Education Exchange

61 Historical Note

63 Library

72 Calendar

75 Classified

78 Advertisers in This Issue

79 Posterminaries

ON THE COVER: Test using high-temperature gas flow to evaluate a hemispherical functionally gradient material. From M. Koizumi and $M$. Niino in this issue, p. 20. For more information on functionally gradient materials, please see the section that begins on page 14 . 


\section{Research Society}

The Materials Research Society (MRS), a nonprofit scientific association founded in 1973, promotes interdisciplinary goal-oriented basic research on materials of technological importance. Membership in the Society includes nearly 11,600 scientists, engineers, and research managers from industrial, government, and university research laboratories in the United States and nearly 50 countries.

TheSociety's interdisciplinary approach differs from that of single-discipline professional societies because it promotes information exchange across the many technical fields touching materials development. MRS sponsors two major international annual meetings encompassing approximately 50 topical symposia, and also sponsors numerous single-topic scientific meetings. The Society recognizes professional and technical excellence, conducts short courses, and fosters technical interaction in local geographic regions through Sections and University Chapters.

MRS participates in the international arena of materials research through the International Union of Materials Research Societies (IUMRS). MRS is an affiliate of the American Institute of Physics.

MRS publishes symposium proceedings, MRS Bulletin, Journal of Materials Research, and other publications related to current research activities.

MRS Bulletin (ISSN: 0883-7694) is published 12 times a year by the Materials Research Society 9800 McKnight Road, Pittsburgh, PA 15237 Application to mail at second class rates has been approved at Pittsburgh, PA and at additional mailing offices. POSTMASTER: Send address changes to MRS Bulletin in care of the Materials Research Society, at the address listed phone (412) 367-3003; fax (412) 367-4373 Printed in the U.S.A.

Additional copies of articles in the MRS Bulletin may be made at $\$ 2.50$ per article. This fee can be paid to the Materials Research Society through the Copyright Clearance Center Inc., 27 Congress Street, Salem, MA 01970.

Membership in MRS is $\$ 75$ annually for regular members, $\$ 25$ for students and retired members. Dues include an allocation of $\$ 29$ ( $\$ 17$ for students and retirees) to a subscription to MRS Bulletin. Individual member subscriptions are for personal use only. Non-member subscription rates are $\$ 120$ for one calendar year (12 issues) within the U.S.A. and $\$ 175$ elsew here. Single copies may be purchased for $\$ 16$ each. Send subscription orders to Subscription Department, Materials Research Society, 9800 McKnight Road, Pittsburgh, PA 15237 .

MRS Bulletin is included in Current Contents" / Engineering, Computing, and Technology Current Contents $/$ Physical, Chemical, and Earth Sciences, the SciSearch online database, Re search Alert, and the Materials Science Citation Index"'. Back volumes of MRS Bulletin are available in $16 \mathrm{~mm}$ microfilm, $35 \mathrm{~mm}$ microfilm, or $105 \mathrm{~mm}$ microfiche through University Microfilms Inc., 300 North Zeeb Road, Ann Arbor Michigan 48106.

\section{Materials Research Society 9800 McKnight Road \\ Pittsburgh, PA 15237-6006}

Tel. (412) 367-3003; Fax (412) 367-4373

Editorial Office • 9800 McKnight Road • Piltsburgh, PA 15237-6006 Tel. (412) 367-3003; fax (412) 367-4373

Publisher

G.A. Oare

Editor

E.L. Fleischer

Managing Editor

J. Meiksin

Assistant Editor

L.R. Gallagher

Copy Editors

J. Guenther, L.A. Krysinski,

and $M$. Wilmoth

Art Director

C. Love

Design/Production

T. Aiello and S. Franklin

CHAIR-EDITORIAL BOARDS

E.N. Kaufmann • Argonne National Laboratory • Argonne, Illinois, USA

\section{INTERNATIONAL ADVISORY BOARD}

M. Balkanski

University of Pierre and Marie Curie

Paris, France

R.G. Elliman

Australian National University

Canberra, Australia

S. Hsu

Chung Shan Institute of Science and Technology, Retired

Taiwan, China

TECHNICAL EDITORIAL BOARO

J.C. Bravman

Stanford University

Stanford, California, USA

C.W. Draper

AT\&T Engineering Research Center

Princeton, New Jersey, USA

E. Fogarassy

Centre de Recherches Nucléaires

Strasbourg, France

Editorial Assistants
M.M. Costello and J. Dininny
Advertising
M.E. Kaufold
Circulation
S.E. Krasa
Guest Editors
B.H. Rabin and I. Shiota
Special Contributors
K.J. Anderson, N. Bolen,
J.R. Horan, B. Horowitz,
A. Sutton, and L. Schneemeyer
Special Consultant
M. Goodway

Associate Editor-Europe

I.W. Boyd

University College London

Dept. of Electronic and

Electrical Engineering

Torrington Place

London WCI E7 JE, U.K.

Tel. 71-387-7050 ext. 3956 or 7304

Book Review Editor

C.J. McHargue

University of Tennessee

Knoxville, Tennessee

MRS Office of Public Affairs

555 13th Street NW, Suite 900 East

Washington, DC 20004

Tel. (202) 383-8809, Fax (202) 383-8877

\section{L.C. Ianniello \\ U.S. Department of Energy, Retired \\ Washington, DC, USA \\ H-D. Li}

National Science Foundation-China

Beijing, China

P. Rama Rao

Ministry of Science and

Technology

New Delhi, India
R. Roy

The Pennsylvania State University

University Park, Pennsylvania, USA

T. Sugano

Toyo University

Tokyo, Japan

D.L. Weaire

Dublin, Ireland
University of Dublin

\section{Chasbourg, France}

MRS BULLETIN PUBLICATIONS SUBCOMMITTEE

\section{A.J. Hurd}

Sandia National Laboratories

Albuquerque, New Mexico

M.R. Libera

Stevens Institute of Technology

Hoboken, New Jersey

D.B. Poker

\section{F.Y. Fradin}

Argonne, Illinois, USA

B.M. León

Universidad de Vigo

Vigo, Spain

G.L. Liedl

Purdue University

West Lafayette, Indiana, USA
Argonne National Laboratory

\section{S. Namba}

Osaka University

Osaka, Japan

A.D. Romig Jr.

Sandia National Laboratories

Albuquerque, New Mexico, USA

J. Soares

Universidade de Lisboa

Lisboa, Portugal

K.C. Taylor

General Motors R\&D Center

Warren, Michigan, USA

\section{S.M. Prokes}

Naval Research Laboratory

Washington, DC

AT\&T Bell Laboratories

Murray Hill, New Jersey

Oak Ridge National Laboratory

C.W. White

Oak Ridge National Laboratory

Oak Ridge, Tennessee
Oak Ridge, Tennessee

\section{MRS EXECUTIVE COMMITTEE}

President

Julia M. Phillips

AT\&T Bell Laboratories

First Vice President and President-Elect Carl V. Thompson

Massachusetts Institute of Technology

Second Vice President

Robert Hull

University of Virginia
Secretary

Carl C. Koch

North Carolina State University

Treasurer

A. Kay Hays

Sandia National Laboratories
Immediate Past President

John C. Bravman

Stanford University

Executive Director

Materials Research Society

John B. Ballance

\section{INTERNATIONAL UNION OF MATERIALS RESEARCH SOCIETIES}

President

Paul Siffert

Centre de Recherches Nucléaires,

France

Tel. (33) 88106543 ; Fax (33) 88106293

IUMRS ADHERING BODIES

Australian Materials Research Society (A-MRS)

J.S. Williams

Chinese Materials Research Society (C-MRS)

Hengde Li

European Materials Research Society (E-MRS)

P.A. Glasow
Vice President

Masao Doyama

Nishi-Tokyo University, Japan

Tel. (81) 333390519 ;
Fax (81) 333100931
Secretary

Rodney C. Ewing

University of New Mexico, USA

Tel. (505) 277-4163

Fax (505) 277-0090
Treasurer

Li-Chung Lee

ITRI, Taiwan

Tel. (886) 35-820205

Fax (886) 35-820247
Immediate Past President

Secretary General

R.P.H. Chang

Northwestern University, USA

Tel. (708) 491-3598; Fax (708) 491-4181

Materials Research Society of Korea (MRS-Korea)
Min Che Chon
Materials Research Society of Taiwan (MRS-T)
Li-Chung Lee
Mexican Materials Research Society (Mexican-MRS)
M.J. Yacamán

Materials Research Society (MRS)

J.M. Philips

Materials Research Society of India (MRS-I) 